\title{
2 Mapping the Black Women's Renaissance: The Formative 1970s and the Shift from a Black Nationalist to a Black Womanist Aesthetic
}

\subsection{Ninety-seventies' Feminist Social Protest Fiction: Race, Class, Gender, Sexuality and Motherhood}

The Black Aesthetic literary program was centered on race; it disregarded gender and other markers of identity that did not fit neatly into a unitary concept of "blackness." As Deborah McDowell explains in "Boundaries: Or Distant Relations and Close Kin," a chapter in her book, “The Changing Same”: Black Women's Literature, Criticism, and Theory, the founding assumptions of BN were that: "(1) the world is neatly divided into black and white; (2) race is the sole determinant of being and identity, subsuming sexual as well as other forms of difference; (3) identity is pre-existent, coherent and known; and (4) literature has the power to unify and liberate the race" (103). McDowell admits that Black Aesthetic poets, artists and theorists should be credited with the deconstruction of negative stereotypes of black people, which was a very empowering and liberating strategy in the 1960s. However, as McDowell also claims, this strategy of presenting only positive images of blackness eventually became dogmatic and confining, and this approach, unified around an overarching signifier of race, precluded exploration of inherent differences within black communities.

While black communities remained a primary topic of the BWR novels, by contrast with the assumptions of the Black Aesthetic, women writers of the 1970s presented these communities with unblinking realism. They no longer treated blackness as a monolithic category, in which race, rather than sexuality, class or gender, was the main determinant of the self. Even though these novels avoided the theme of blackand-white wars, they showed how African American communities were tragically damaged by white racism. They demonstrated how structural violence, racism, economic deprivation and the internalization of cultural stereotyping impinged on black people's self-actualization, self-esteem and relationships within the family and community. In other words, they showed what Madhu Dubey called the "displaced effect" (Black Women Novelists 109) of white racism and how it was transformed into gender oppression. These novels left no doubt that the victimization of black women and their sexual and economic exploitation were a direct result of men transferring onto women the effects of their own brutalization (Hairston, "Works of Rare Beauty" 177).

While BN thinkers talked about the Black Aesthetic as a cultural program that could elevate black people from denigration and oppression, the Second Renaissance writers in the 1970s outdistanced most of their male predecessors in their toughminded reappraisal of the social problems that plagued African American communi- 
ties. Black nationalists focused on what the future of black people in America might be if they lived up to the expectations of the black nationalist political and cultural program. BWR writers, by contrast, seemed too aware of the sordid reality of life for African Americans, particularly women, to waste their time on the idealized projections of the Black Aesthetic, which were vague and removed from reality. The 1970s' novels of BWR writers set forth their bleaker, or simply more realistic, vision of the social conditions that shaped, or rather warped, black people's lives.

In the words of Madhu Dubey, the writers of the BWR introduced a "productive interplay of differences" to "subvert ideological celebration of a unified black community" (Black Women Novelists 153). These female authors wrote novels that flew in the face of the BN injunction that black art should correct white claims of black pathology. Conversely, they created characters who moved dangerously close to negative stereotypes of black people. Toni Morrison's The Bluest Eye, for example, portrayed a family affected by rape, incest, and madness, which could be seen as an illustration of the notorious Moynihan Report about dysfunctional black families. Likewise, Alice Walker's The Third Life of Grange Copeland portrayed black men brutally oppressing black women (most notably, Mem, the mother of the main female protagonist, Ruth, is mercilessly abused by her degraded husband). Gayl Jones's Corregidora seemed to reiterate one of the central findings of the Moynihan Report that identified black matriarchy as the most damaging legacy of slavery. Corregidora features black matriarchs passing on to their female offspring disturbing memories of slavery and a bitter hatred towards all men. The novel tapped into BCN's critique of matriarchy as a force that comes between black women and men and "obstructs the development of the healthy relationship between black men and women; [as] the women's primary allegiance is to the maintenance of the matriarchy rather than marriage" (Dubey, Black Women Novelists 74). Gayl Jones's second novel, Eva's Man, focuses on gender and sexual warfare to an even greater extent than Corregidora, playing with what Harry Reed termed "the Madonna/bitch theme" ("Toni Morrison" 56). Its eponymous protagonist, Eva, kills and castrates her lover when she realizes he wants to abandon her. Most 1970s' novels, such as Jones's Corregidora and Morrison's The Bluest Eye and Sula, focused on bigoted black communities that found it difficult to come to terms with various singularities of black women. Some novels critiqued the conservatism of the urban community (Morrison's Sula and Song of Solomon, Jones's Corregidora, Alice Walker's Meridian), be it political, religious or sexual.

The 1970s' novels also revealed the heterogeneity of black communities by broaching the subject of class divisions. According to Henry Louis Gates Jr., the issue of class had been an ongoing concern for African American writers such as Alain Locke, W.E.B. Du Bois, Jessie Fauset, Nella Larsen, and Ann Petry, all of whom had looked closely at the issue of class consciousness among African Americans. However, as the century progressed, concerns about class were increasingly eclipsed by anger about racism. Then, in the 1970s, as Gates has pointed out, class-conflict again became central. The two decades of the 1970s and 1980s saw an increasing separation of 
middle-class professional blacks from working class African Americans. Middle-class blacks lived in different communities and went to different schools and churches than working class and poor blacks. Thus, class reasserted itself also as a topic of literature (Gates, "Introduction” 2018). The theme of class conflict was most pronounced in the 1970s in novels such as Brown Girl, Brownstones (Marshall), Meridian (Walker), and Song of Solomon (Morrison); and later, in the 1980s, in Tar Baby (Morrison), Praisesong for the Widow (Marshall), and The Women of Brewster Place and Linden Hills (Gloria Naylor).

Particularly in 1980s' novels, upward class mobility was roundly condemned as a major threat that disrupted the unity of black people that the volkish tradition would painstakingly try to restore. Contrary to what Gates claims, this engagement with class divisions was rather tokenistic and superfluous. As E. Frances White has claimed in "Africa on My Mind," even though the novels showed divergent class interests among African Americans, their focus was not really on class conflict, disparities in status, distribution of wealth, discrimination in the workplace and access to education, but rather on identity politics. For example, Praisesong for the Widow ends with Avey's resolution to ensure the continuity of African diasporic practices and rituals by passing them on to her offspring. What remains unspoken is the fact that Avey will return to her middle-class home in the suburbs. By ending the novel before she actually goes home, Marshall obscures class differences between Avey and the islanders who brought about her spiritual transformation. She also glosses over the fact that most Africans Americans could not afford to go on a trip to the Caribbean to reconnect with their African "nations." Another well-known novel that acknowledges class disparities but then glosses over them is Gloria Naylor's Mama Day. The novel does not address the apparent class differences between George, a partner in an engineering firm, striving to achieve the American dream, and the working-class Cocoa, who resorts to magic to find a job. Soon, her lack of employment becomes irrelevant when instead of getting a job, she gets a husband and becomes a black professional's wife. The novel does not elaborate on the stark contrast between George's affluence and the impoverishment of the rural community of Willow Springs that he would like to call his home. None of these novels tackles the issues of class privilege and cultural tourism, and such elisions put the BWR within what Cornel West called "liberal capitalist perimeters" ("The Paradox" 22). He states that "despite [their] powerful and progressive critique of American cultural imperialism," BWR writers and Afrocentric critics alike were advocates "of Black petit bourgeoisie" indulging in "self-congratulation and self-justification upon reaching an anxiety-ridden middle class status" (ibid. 32), a point to which I will return later.

The communities that emerged from the black female narratives of the 1970s were, first and foremost, rife with gender conflict and anxiety about the time-honored roles of women as "Obedient Daughter[s]," "Devoted [Wives]," and "Adoring Mother[s]" (Alice Walker, Meridian 19). BWR novels of the 1970s debunked almost all these assumptions about perfect black womanhood, "imagin[ing] a different script 
for women” (McDowell, “The Changing Same” 103). Although these novels retained a didactic and functional character, as far as gender and sexuality were concerned, they represented a backlash against and a corrective to the gender dictates of black cultural nationalism. In this first decade of the BWR, black women writers were in constant dialogue with the tenets of black cultural nationalism, which seriously impacted on the psychological delineation of character in their novels. Whereas for black nationalists the primary goal of a black artist was to portray black "people" (read men) in a positive light, for BWR writers the goal was to present unbiased and full characterizations of black women (Dubey, Black Women Novelists 2). Even if these novels engaged with stereotypes from either white or black nationalist discourses (nanny, matriarch, jezebel), sometimes dismantling them (The Third Life, Meridian, Sula), and sometimes reifying them (Corregidora, The Bluest Eye), they did it with the intention of creating rounded and more idiosyncratic characterizations of women. By creating fully-fledged and complex psychological portraits of female characters, which were well-grounded in contemporary political and social reality, these texts revealed the full and equivocal nature of black feminist subjectivity.

Therefore, as Madhu Dubey states, the BWR narratives of the 1970s challenged the "notion of a whole and unified self as an unrepresentable, imaginary ideal" (Black Women Novelists 5), and ushered in more ambiguous renderings of black womanhood, especially when they produced contentious black female protagonists, such as Mrs. Breedlove, Sula, or the "Corregidora women." In these novels female characterization often bordered on caricature, and the writers used the grotesque to target vicious racial, gender and sexual stereotypes. The use of the grotesque mode had already been advocated by BN writers with a view to ridiculing white middle-class cultural models and norms. But BWR writers used it to show the ramifications of gender stereotyping in the mainstream white and black nationalist rhetoric. The 1970s' novels often have "flat, projective models of characterization" (Dubey, Black Women Novelists 93) that bring to mind current discourses about black femininity (matriarch, Jezebel etc.). For example, Eva's Man, “relentlessly constructs identity in stereotypical terms” (Dubey, Black Women Novelists 93). Instead of presenting new black subjectivity, the novel rehearses ad nauseam the old, perverse and grotesque images of black bucks and castrating bitches. The novel presents black men as primitive sexual creatures "limited to animal dynamics," but it also very clearly shows black women's complicity in acting out men's fantasies of female avengers and emasculators. By taking these stereotypes to extremes, Eva's Man demonstrated their full and unacknowledged destructive power. Similarly, The Bluest Eye shocked readers by conjuring up stereotypical images of self-despising black women who look to white culture for an ideal of beauty. These characters stand for the mainstream view of black identity as a distorted mimicry of black nationalist rhetoric or middle-class white standards. In Sula, on the other hand, as Dubey argues, the grotesque is used to delineate sharply the extremes that the characters represent. While Sula stands for newness, individuality, and change, her more traditional friend, Nel, connotes passivity, conformism, and fear of change and 
progress. Both characters are grotesque because they cling to diametrically opposed extreme values, with Morrison seeming to suggest that "if they had been one person" she would be truly "marvelous." (Stepto, “Intimate Things in Place” 13). In Dubey's words, the use of the grotesque in all these novels shows "black feminine identity as unfinished and heterogeneous” (Black Women Novelists 141).

The novels of the 1970s were more intrepid in their search for what bell hooks has called a radical black female subjectivity ("Revolutionary Black Women” 224) free of the stereotypes and conservative injunctions of black nationalism, even though their authors were at odds about what radicalism really means. In that context, Sula is often cited as the prototype of the radical black feminist novel. In two mutually exclusive readings of the novel, Sula is presented as either the embodiment of the newness that the black nationalists called for (but only for men), or of the individualism that black cultural nationalism resoundingly condemned. Either way, Sula, whom bell hooks sees as the closest approximation of radical black womanhood (ibid.), is denounced by Morrison who presents her as a grotesque character (Stepto, "Intimate Things in Place” 13). In this way, Morrison indicates that Sula's radical separation from traditional models of black femininity makes her merely a defiant oddity who does not have any positive impact on her community. But Sula's very uncompromising defiance, as hooks aptly remarks ("Revolutionary Black Women" 224), is what makes her stand out among other black female characters of the BWR. Sula not only represents a radical rejection of the past, the legacy of victimhood and passivity, but also stands for the untrammeled sexuality and vigor that black cultural nationalism ascribed only to men. Sula's promiscuity wreaks havoc on men's vanity by showing them the extent to which she does not care about them. As McDowell has observed, "Sula's female heritage is an unbroken line of 'manloving' women who exist as sexually desiring subjects rather than as objects of male desire" ("The Changing Same" 106).

Some black female critics, most notably Barbara Smith, proposed a reading of Sula as an early lesbian novel that privileges female bonding over male-female relationships: "[Sula] works as a lesbian novel not only because of the passionate friendship between Nel and Sula, but because of Morrison's consistently critical stance toward the heterosexual institutions of male/female relationships, marriage and the family' (Smith, qtd. in Dubey, Black Women Novelists 55). Such a stance was representative of the novels that condemned heterosexuality, but nonetheless, generally steered clear of the topic of lesbian relations. Therefore, while some 1970s' novels, such as Eva's Man, Sula and Corregidora, had some hints of homosexual desire, none of them ventured far beyond the heterosexual parameters of black cultural nationalist formulation of blackness. Gloria Joseph explains in "Black Mothers and Daughters" that black women's resistance to lesbianism in the 1970s was a result of their partial capitulation to black cultural nationalist homophobic rhetoric. Black Nationalists often attacked lesbians as "men-haters" who consciously excluded themselves from the movement that wanted black men and women to work together to combat racism. Lesbianism was also seen as a threat to the whole concept of the Black family or the Black commu- 
nity or the Black male-female relationship. Therefore, the 1970s can at best be lauded for launching what Gloria Wade-Gayles calls "the tradition of latent lesbian fiction" (No Crystal Stair 175, emphasis added). In fact, lesbian love as a special kind of female bonding was practically invented as a theme in BWR fiction in the 1980s. While the novels of the 1970s paved the way for an affirmation of lesbianism with their scathing critique of the compulsory heterosexuality that was equated with violence against women, the next decade saw the emergence of the proper lesbian novel with the publication, in 1982, of two famous books: Zami: A New Spelling of My Name by Audre Lorde, and The Color Purple by Alice Walker.

The 1970s' novels may be reticent on the issue of homoerotic desire but, on the other hand, they are remarkable for their controversial renderings of black motherhood, a topic of great importance in any nationalist discourse. These renderings seemed to have more in common with the white feminist critique of harnessing motherhood in the service of family, capitalist society, and the nation, than with more commonplace endorsements of motherhood by black women. Sula, for example, is pictured as an "unnatural” (and evil) woman who famously proclaims "I don't want to make anybody else. I want to make myself” (Morrison, Sula 92). This assertion comes as no surprise to the reader, since in this novel, motherhood, even though it is valued by the black community, is not presented as an experience that is fulfilling for mothers themselves. Doting mothers, who do not have their own lives, such as Helen Wright, Nel's mother, are placed on the same level as deficient mothers who abandon their children or even kill them, such as Eva Peace.

Other 1970s' novels also picture the experience of motherhood as an oppressive burden, a kind of "slavery" rather than "secret joy" (Alice Walker, Meridian 69; 51). Walker's Meridian goes even further than Sula in deconstructing black cultural concept of the heroic black mother of revolutionaries. The novel demystifies mothering by representing it as life-breaking drudgery, and children as devourers of their young mothers' "emerging self" (51). In its bid to reinstate black women themselves as the revolutionaries, rather than just their mothers, the novel seems to reinforce the black cultural nationalist idea that, for a revolutionary, child-raising is a dead weight that impedes the struggle. While Meridian's mother sacrifices herself on the altar of motherhood (and political and religious conservatism), the revolutionary Meridian sees motherhood as incompatible with being a social activist. She abandons her son, has an abortion and eventually has her tubes tied up, to the utter horror of her lover Truman, who represents a typical black nationalist mindset. Meridian depicts pregnancy as an undesirable and potentially dangerous trap that makes black women highly vulnerable. Nel's pregnancy in Sula is described by Walker as her "fall” (88), and her mother's pregnancies are as sickness accompanied by hair loss that "signals her successive loss of herself in her children" (Dubey, Black Women Novelists 130). Mem's pregnancies, in The Third Life of Grange Copeland, destroy her health and ultimately cost her life. 
Corregidora critiques not only the biological and social essentialism of motherhood; it also puts down the whole black nationalist reproductive ideology. The "Corregidora women," black matriarchs who used to be Corregidora's slaves, and who use procreation to pass on the story of their own abuse, talk of motherhood as something their bodies "wanted," a natural instinct, an irresistible urge. This natural female desire is linked to their pride in black women's capacity to "make generations" of witnesses whose memories are living archives (Corregidora 22). They "mythicize their oppressive history, and thus are unable to perceive it as history, or to envision a future untainted by the slavery creed" (Dubey, Black Women Novelists 78). But the novel questions this essentialist urge and the reproductive myth by showing motherhood as a social and cultural construct that is highly problematic. Ursa, Corregidora's main protagonist, juxtaposes her mother's narrative with her own observations of young women who were shamed and broken because of their unwanted pregnancies. She doubts whether, if she could have children, she would go along with the custom of passing on to her daughters the harrowing family history about Corregidora. The novel condemns using procreation as a means of achieving political goals, and dramatizes the repressive consequences of a reproductive definition of black woman as a "slavebreeder's way of thinking” (Corregidora 22). Ursa's rejection of Corregidora's women's legacy, Meridian's decision to become a motherless and childless revolutionary, and Meridian's embedded stories of the childless rebels, Louvinie and Fast Mary, all seem to suggest that there is a forgotten tradition of black women who should be valued for their recalcitrant spirit that puts them on a par with revolutionary black men. Ursa, who is sterile, and other female characters who refuse to have children (like Meridian or Sula) or who kill their children (like Eva Peace) become symbols of a non-reproductive black femininity that refuses to be bound by reproductive determinism.

These 1970s' novels deconstructed black motherhood and exposed difficulties in the mother-daughter dyad. They featured black women who adopted the myth of self-actualization through motherhood and nurturing and then often found themselves in a trap. Moreover, as Dubey points out, The Third Life of Grange Copeland, The Bluest Eye, Sula and Corregidora "[foregrounded] the mutually antagonistic relationship between parents and children” (Black Women Novelists 113), particularly between mothers and daughters. Sula's mother hates Sula, and Sula hates her back. Meridian cuts off all ties with her mother, Ursa chooses a life with her husband Mat, ultimately pledging allegiance to the institution of marriage rather than the matriarchy (Black Women Novelists 74). In fact, as Mary Helen Washington argued in her 1975 anthology, Black-Eyed Susans: Classic Stories by and about Black Women, the conflict between fictional daughters and their mothers and grandmothers was seen as one of the major themes in black female writing, dating back to such precursors as Zora Neale Hurston's Their Eyes Were Watching God (1937), Dorothy West's The Living is Easy (1948), and Lorraine Hansberry's A Raisin in the Sun (1959). Interestingly, by the 1980s, the theme of intergenerational conflict between black daughters 
and their pragmatic and overprotective mothers was salient only in the writings of African Caribbean authors: Audre Lorde’s Zami: A New Spelling of My Name (1982), Paule Marshall's Brown Girls, Brownstone (1981), Jamaica Kincaid's Annie John (1985) and Lucy (1990), and Michelle Cliff's Claire Savage novels (1984 and 1987).

Yet in spite of the 1970s' focus on the underside of motherhood and the generation gap, the BWR affirmed, in one way or other, the centrality of mothers and matrilineage in African American culture. Some of these novels, most notably Song of Solomon, even seemed to anticipate the 1980s' idea that the relationship between mother/grandmother/aunt and child can be the most effective way to cultivate black folk culture. In this way, these narratives played with a fundamental nationalist tenet that sees mothers as keepers of traditions and guardians of heritage. The concept of generational continuity and the role of mothers and maternal figures in its procurement was an understated, but discernible, theme in the BWR fiction of the 1970s. As Dubey remarks, for example, The Third Life of Grange Copeland portrays severely strained mother-daughter relationships, but at the same time, it also "displaces the politically transformative potential of the mother-daughter relationship ... to the relationship between the girl and her father" (Black Women Novelists 114). The eponymous Grange who “mothers” his granddaughter, Ruth, after her mother, Mem, dies, teaches Ruth self-esteem and survival through black cultural history and oral folk history. While other novels overtly reject self-sacrificial black motherhood, they seem, at the same time, to mourn "the standard of motherhood that had gone before" (Alice Walker, Meridian 91). Meridian and Ursa, are aware of the yawning gap between their ambivalent experiences of and thoughts about motherhood and their female ancestors' unconditional and absolute endorsement of it. Meridian's thoughts often revolve around slave women's definition of freedom as the ability to "keep their own children" (Meridian 91). Meridian thinks that "as far as she knew," she was "the only member" of "an unworthy minority, for which there was no precedent” (ibid.). Both Meridian and Ursa "distance themselves from reproductive ideologies in order to liberate a new black feminine identity free of the oppressive cycle of the past" (Dubey, Black Women Novelists 160), but at the same time, they are wracked with guilt by the immensity of their betrayal. Sula, who is not, is unequivocally censured by Morrison (and the critic Barbara Christian) for her disregard for her mother and grandmother, the guarantors of temporal and natural continuity. Thus, these novels can be read, I think, as an expression of the vexed relationship between these protagonists' desire to reject black nationalist reproductive ideologies and their converse belief that "the womb ... [is] an important means of political resistance" (Dubey, Black Women Novelists 160). It was only later, in the 1980s, that BWR writers finally resolved this contradiction by jumping on the nationalist bandwagon and making motherhood the bedrock of their own culturalist version of black nationalism, as I will argue in the following chapters. 


\subsection{Forging of Black Womanist Aesthetic}

If we look at Corregidora and Eva's Man by Gayl Jones and the way they tackled the issue of generational continuity, motherhood, black heritage and history, it becomes clear why Jones' reputation fell into decline in the 1980s. It seems that Gayl Jones was the only BWR writer who did not go with the nationalist tide. While Corregidora seems, in fact, to have invented the 1980s' trend that saw mothers as carriers of black heritage and history, the novel's unflattering rendition of matrilineage and its refusal to endow it with any redeeming possibilities went against the grain of the volkish tradition that flourished in the 1980s. According to Dubey, Eva's Man also hinted at the importance of female bloodlines: "Eva's Man implies that only a recovery of ancestral continuity can redeem the senseless temporal cycle that imprisons Eva” (Dubey, Black Women Novelists 96). But in my opinion, the logic of the novel does not bear out such a claim. The ancestors' bracelet that Eva receives from her mother's friend Miss Billie, a wise grandmother figure that is a mainstay of the 1980s' volkish tradition, is a symbol for intergenerational continuity that empowers young women by encouraging them to remain "true to one's ancestors"; that is, to maternal figures who are regarded as role models. As Dubey says, the bracelet "seems to symbolize a temporal continuity dependent on reproduction" (Black Women Novelists 97), and in this sense, it perpetuates another cultural stereotype: namely, that a woman's body is a medium for "[t]hose people who came before you and those who came after you" (Corregidora 22). Though Eva values the bracelet, it does not become for her anything more than a beautiful trinket, contrary to what Dubey suggests. The bracelet, which Eva quickly loses, seems to be as useless as the stereotype-ridden stories about Queen Bees that Eva hears from Miss Billie. One could even argue that, as in the case of Ursa, maternal stories, and the preference for matriliny that they connote, are severely damaging to Eva, as they deform her budding sexual identity. Thus, neither Corregidora nor Eva's Man show intergenerational female bonding as empowering for young women. There are no edifying stories or role models that the older women in these novels have to pass on to the younger generation; that is, no stories, that are not tied up in knots of stereotypical thinking about gender and sexuality. The story of Eva's namesake, a Gypsy called Medina befriended by her great-grandmother, is the only story in the novel that is not undercut by confining racial and gender stereotypes. As Dubey herself admits, however, "Eva's continuity with Medina does not go beyond the external details of name, appearance and physical mobility” (Black Women Novelists 98).

By contrast, if we look at Alice Walker's early novels, it is clear why she entered the circle of the few empowered texts of the canon of African American literature. In my opinion, Walker's 1970s' novels can be seen as transitional texts between the masculine black nationalism of the 1960s and the second decade of the BWR in the 1980s. The Third Life of Grange Copeland and Meridian were the most political novels of the BWR, dealing directly with such topical issues as feminism, the southern Civil Rights Movement, the Northern Black Power movement, the black aesthetic and the place 
of black women in those discourses. Walker's novels represent not only a head-on confrontation with black cultural nationalism, in which Walker took to task the masculine black nationalist construction of community that sidestepped the concerns of black women. They were, first and foremost, very astute attempts to merge black cultural nationalism with feminism. The result of this fusion was womanism, a specific brand of black feminism that was destined to become the dominant ideology for the 1980s' BWR writers. Dubey is right, therefore, when she claims that “[ $t$ ]he term womanism ... may be interpreted as an attempt to integrate black nationalism into feminism, to articulate a distinctively black feminism that shares some of the objectives of black nationalist ideology" (Black Women Novelists 107)..$^{33}$

Both of Walker's 1970s' novels come to grips with masculine cultural nationalism by introducing unlovable male nationalist characters and "feminizing," or rather "womanizing," them to make them acceptable. Thus, Grange is a typical Black Power Movement fighter who transforms from a degenerate killer into a protective family man. In his former "pre-womanist" life, Grange kills a white pregnant woman and his own abusive and degenerate son; the latter murder is justified by Grange's desire to protect his granddaughter Ruth, whom he refers to as the "womanish gal" (251). In this way, Dubey claims, "the man who kills his own son is also the figurative mother who performs the crucial womanist task of preserving and transmitting the black cultural past to succeeding generations," (Black Women Novelists 119). She adds that " $[\mathrm{t}]$ hrough the figure of Grange the novel establishes black nationalism as the precondition of its own womanist redefinition of historical change" (Black Women Novelists 119). In other words, in the tradition of the Bildungsroman, Grange's development into a responsible and caring state of manhood is a prerequisite for Ruth's development into a state of womanist, politically conscious, womanhood. Thus, the novel shifts its focus from the reformed black nationalist man to his womanist granddaughter and heir. In this way, it seems to project the transfer of power, prestige and centrality from black nationalist men to BWR writers. But this new focus on "the womanist gal" should not blind us to the fact that the "refocusing of history around the black woman ... subsumes rather than negates the historical vision of black nationalism," as Dubey has put it (Black Women Novelists 119).

Likewise, Meridian could be seen as a Künstlerroman due to its characterization of Truman, a representative of the Black Arts Movement. Described as "courageous and new" (100), Truman is a quintessential black aesthetic artist who glorifies African "superwomen" in his art and sculpts “voluptuous” African Earth mothers (Meridian

33 In Phillips's "Introduction" to her edited collection, The Womanist Reader: The First Quarter Century of Womanist Thought, she says that examples of womanist novels, besides Toni Morrison's The Bluest Eye and Song of Solomon include: Margaret Walker's Jubilee; Paule Marshall's The Chosen Place, the Timeless People and Praisesong for the Widow; and Alice Walker's The Third Life of Grange Copeland and The Color Purple. 
113). He encourages Meridian to "have his beautiful Black babies," who would become "the warriors of the new universe" (Meridian 16; 168). According to Dubey, contrary to The Third Life of Grange Copeland, which "attempts an integration of black nationalism and womanism, Meridian admits no compromise with Black nationalist ideology” (Black Women Novelists 126). Notwithstanding this observation, which I only partially agree with, Meridian does end on a similar note to The Third Life of Grange Copeland, when Truman, like Grange, nurtures Meridian when she is sick, thus stepping into a "maternal” role. These novels, can be linked to Alice Walker's 1985 masterpiece, The Color Purple, as they all manifest Walker's apparent desire to "disarm" and "feminize" men who are too masculine (Sadoff, "Black Matrilineage" 24), and to restore women, such as Ruth from The Third Life of Grange Copeland, and Meridian, or Celie, Sophia, Shug Avery, and Squeak from The Color Purple to more central positions. These womanist narratives seem to suggest that women are the driving force in black communities and that to gain women's approval and admiration, men must become a little bit more like them, by learning to manifest womanist features.

The Third Life of Grange Copeland (1970) and Meridian (1976) were the earliest expressions of Walker's philosophy of womanism that grappled with the inherent contradictions of black cultural nationalism and tested the extent to which it could be compatible with black feminism. When Walker published her seminal collection of essays and speeches on the womanist aesthetic in 1983, In Search of Our Mother's Gardens: Womanist Prose (written between 1967 and 1983), black cultural nationalism emerged, in my opinion, as a philosophy that was seen as being not only compatible with, but actually beneficial for black feminism. Walker's womanist writing incorporated and transformed the radical elements of black nationalism, turning them into a much more moderate, but equally powerful, theory that exceeded the bounds of the Black Aesthetic ideology and paved the way for the 1980s' volkish tradition, as I will argue later.

Womanism can best be defined as incorporating a black female genealogy and female knowledge that bypasses the patriarchal episteme through female bonding and descent. It is a philosophy that celebrates the same values that were cherished by male black nationalists: namely, black communitarianism, the spirituality of black diasporic cultures, vernacular traditions and, generally speaking, the "ideals of black life” (Ogunyemi, "Womanism” 28). Contrary to male BCN, womanism appreciated ancestry and heritage Layli Phillips, for example, stated that "to be a womanist, one must identify one's cultural roots and experience oneself as a cultural or ethnic being" ("Introduction" The Womanist Reader xxxvi). Womanism also countered masculine black nationalism with its desire to "[give] a balanced representation of black womanhood" (Ogunyemi, "Womanism" 28) and to focus on "common" black women as the subject of its discourse. For Walker, womanism was, above all, the special relationship that common black women had with one another and with their mothers 
and daughters. Walker and her followers ${ }^{34}$ presented womanism as a holistic black philosophical system that was "rooted" in female folk heritage, or, as Walker put it, in black "mothers' gardens." These gardens were not only tangible proofs of the creativity and ingenuity of simple, uneducated and disenfranchised black women. Planted on infertile soil, they epitomized the female folk legacy and black women's struggles to survive in hostile environments. In brief, they were emblems of Black women's collectively shared oppositional knowledge. Womanism asserted the importance of this oppositional knowledge in preserving the heritage and well-being of African American communities and keeping their memory of the past alive.

Dubey claims that Walker's re-conceptualization of maternal legacies in that collection "initiated the feminist appropriation of the mother as a means of legitimizing a feminine revision of history and cultural tradition" (Black Women Novelists 114). It was a tour-de-force that showed that Walker had managed to work through her earlier agonizing uncertainty about the relevance of motherhood for "anti-oppresionist movements” (Phillips, "Introduction” Womanist Reader xxv). Womanism rehabilitated black mothers as "the most fascinating creations in the world" (Walker, In Search of Our Mothers' Gardens 251). As "headragged generals," 35 they commanded respect and admiration for handing on to their daughters "the creative spark": passion for black folklore, reverence for female bonding and "insights [that] black women gain from their disadvantages and suffering" (Wilson-Tagoe, "Feminism and Womanism" 132). While critics rightly traced the outburst of black female creativity in the 1970s and 80s back to other luminous moments in African American cultural history, such as feminism and the Civil Rights Movement, Walker was adamant in her conviction that for her the most important source of inspiration were common black women, particularly their material and verbal lore. Walker maintained that the enduring legacy that these women passed onto their daughters, including herself, was the belief that the mother-daughter relationship was not only a personal dyad but primarily a special kind of spiritual bonding, a sort of intergenerational link that bestowed on daughters a unique "feminine mystique," and an exclusive womanist worldview. Walker's essays, to a greater extent than her novels, were consistent in "deploy[ing] maternal metaphors to authorize a new black feminine paradigm of cultural transmission” (Dubey, Black Women Novelists 113), presenting black mothers, and female ancestors in general, as the cornerstone of black female identity and the

34 Later contributions to the womanist philosophy focused on other regions, or were global in their scope. Besides Chiwenye Ogunyemi's "Womanism: The Dynamics of the contemporary Black Female Novel in English," see also Clandora Hudson Weem's Africana Womanism: Reclaiming Ourselves, Mary Kolowale's Womanism and African Consciousness, and Tuzyline Allan's Womanist and Feminist Aesthetics: A Comparative Review.

35 This expression is used by Walker in her poem, "Women." 
main source of self-knowledge for all black people. This, for her, was the definition of the womanist aesthetic.

\subsection{The National Family Plot: From the Father of the Nation to the National Mother}

Walker called these common women, who were the pioneers of womanism, foremothers. The term designates black female ancestors, creative black slaves or peasant women, who succeeded in spite of poverty, frequent motherhood, and racial and sexual oppression. A foremother could be a creative genius in quilting, gardening or storytelling. She often had the gift of healing and, occasionally, clairvoyance. She was a religious or spiritual leader, often a visionary. She could offer advice and guidance, teach and protect. Her status as a culture-bearing woman was clear from the outset. As Jacqueline K. Bryant puts it:

[the foremother] is the life force that nurtures her own culture as she repels the influences of the dominant culture that are all too often realized in thought, word, and behavior. The foremother's worldview acts as a protective shield that aids in narrowing the focus to make one see more clearly. (15)

Though the foremother was surrounded by the dominant culture, she never compromised her own cultural beliefs. She did not have education, but she was wise: "clothed in her right mind," as Bryant put it. She intuitively knew what was right and relied on her "mother's wit" (Bryant 20). Her words had regenerative power; they gave her daughters the strength to endure. Mama Day, in the novel by Gloria Naylor of the same title, Pilate in Morrison's Song of Solomon, Aunt Clooney in Paule Marshall's Praisesong for the Widow, Momma Henderson in Angelou's I Know Why the Caged Bird Sings, and Minnie Ransom in The Salt Eaters by Toni Cade Bambara are all examples of such archetypal black foremothers. Each of them "fulfills the critical role of preserving cultural identity," and heals the rifts to "[unify] the tribe" (Braxton, "Ancestral Presence" 305); she keeps the memory of the past and the heritage alive.

Without doubt, BWR writers of the 1980s perceived themselves as the heirs of much-admired folk foremothers, and as mothers of the nascent black feminist literary tradition. This tradition gradually started to emerge from the fervent scholarship of black feminist critics, who set out to save from oblivion the literary "foremothers" of the BWR. The most important foremother for all the writers of the BWR was Zora Neale Hurston, whose ethnographic novels were extolled by Alice Walker. Hurston's prose became a paragon for a black heritage writing, and her feminist agenda and her folk aesthetic played a pivotal role in the formation of the volkish tradition. Hurston's 1937 novel, Their Eyes Were Watching God, which is considered a foundational text of the womanist aesthetic, narrates the "ripening" of the main character, Janie Crawford, 
"from a vibrant, but voiceless, teenage girl into a woman with her finger on the trigger of her own destiny" (National Endowment for the Arts). Set in central and southern Florida in the early 20th century, the novel was initially poorly received on account of its rejection of The Harlem Renaissance's prescription of racial uplift, which assumed that all black people should aspire to be like the white, educated middle class. In the 1980s, however, the novel achieved cult status as a black feminist manifesto. Almost all BWR writers of the 1980s claimed to write in the tradition established by the great literary foremother, Zora. In this way, Hurston's exceptional gift of storytelling and her unprecedented and unique experimentation in combining literature with anthropology, in conjunction with Walker's womanist theories, created a "fashion" for "ethnographic allegories” (Clifford, “On Ethnographic Allegory” 98). It was as if Hurston and Walker "joined hands" to establish, in the BWR fiction of the 1980s, a strong matrilineal tradition that was anchored in Southern black folklore, and privileged women as the keepers of national traditions.

That alliance was, however, contingent on streamlining the work of Hurston, who often contradicted herself, and generally refused to be co-opted by any ideology. This was one of the reasons for her being at odds with other literati of the Harlem Renaissance. Hurston never expressed enthusiasm for black cultural nationalism. On the contrary, in her autobiography, she claimed that there was nothing like "[her] people," and that blacks are just individuals who do not add up to make a people, a nation, or a particular race, as evidenced in her statement that "there is no such thing as Race Solidarity" (Hurston, Dust Tracks on the Road 218). The mature BWN (in the 1980s), on the other hand, insisted on the validity of the nation based on race, and it privileged community over individuality, which was seen as problematic, ambiguous and evil (Sula), and downright unacceptable (Jadine in Tar Baby), especially when associated with climbing the social ladder (Praisesong for the Widow; Tar Baby).

Nonetheless, Their Eyes Were Watching God, can be seen as a prototype of the black family romance novel that tweaks the national family plot and dramatizes a transfer of power from black men to women. Janie's second husband, Jody Starks, can be seen as "the father of the nation." He is an authoritative figure, who, like Hurston's father, founds an all-black town, writes laws for it, and rules it as a mayor. In Hurston's story, he is treated with an irony that comes from the comparison of Jody's achievements to God's acts of creation - the bringing of light and the inscription of laws parody the biblical story of creation and foreground Jody's self-importance and his disproportionate sense of his own "godliness." His self-aggrandizement is evident in his insistence that his higher status is acknowledged. He demands a "high chair" for himself and his wife, Janie, who has presumably achieved her elevated social status through her husband. As is often the case in the masculine version of the national family plot, Janie needs to pay for her social standing by being submissive and self-effacing. The conflict in the novel comes from Janie's reluctance to accept this inferior position. The novel illustrates Hurston's conviction that "her tongue is all de weapon a woman got" when faced with the masculine will-to-power (Mules and Men 33). When Jennie 
lashes out at her husband in public, she symbolically kills him. The novel implies that through "hyperbolic and metaphoric speech," a black woman "earns her power hitherto reserved for the men" (Sadoff, "Black Matrilineage” 17); a message that must have gone down very well among BWR writers.

Though the conflict between Janie and Jody is played out mostly in terms of gender and sexual rivalry, its social context should not be overlooked. Jody is an important, if not the most important, member of the black community; the founding father and the lawgiver. Thus, the small society at the center of which he is placed can be seen as microcosm of the "black nation," in which men, not women, are assigned all politically relevant roles. Janie is put on a pedestal for being the wife of the "founding father," though her position is more that of her husband's trophy and the metaphorical "national mother," even though she remains childless. This fact may suggest Hurston's desire to keep Janie free from the confines of traditional female roles, and her unwillingness to replace patriarchy with a matriarchal hierarchy. Janie remains, in the words of her friend Pheoby, "her own woman," unfettered by any preconceived gender roles (Their Eyes 106).

While the 1970s' novels, like Hurston's writings, were more liberal on the score of idiosyncratic/radical female identities, the onset of the volkish tradition reversed the tendency to portray black women in their full diversity. The womanist subject eulogized by volkish fiction was again "a unified, essential, and whole self” (Dubey, Black Women Novelists 4), which harked back to the black aesthetic ideal of strong, community-oriented and community-bound men and women. The fully-developed womanism of the 1980s endorsed most of the tenets of black nationalism, not only its desire to reverse negative stereotyping. It also shared the deep-seated black nationalist belief in the subordination of art to political agenda, and call for didacticism. On the other hand, womanism went beyond the Black Aesthetics' ideology in its aspiration to give black women their rightful place in the nationalist rhetoric, and to acknowledge their unique contribution to creating and maintaining African American exceptionalism. It redeemed black matriarchs, female networks and lesbian relations. A womanist, claimed Alice Walker, is a woman whose primary allegiance is to other women, rather than men. She is "a woman who loves other women sexually and/or non-sexually. Appreciates and prefers women's culture ... and women's strength ... [and is] committed to survival and wholeness of entire people, male and female" (Walker, In Search of Our Mothers' Gardens xi). ${ }^{36}$ Already in the 1970s, the bourgeoning of womanism had

36 Many definitions of womanism have been offered since Walker's first enunciation of the term; some conflate womanism with black feminism, whereas others emphasize the distinctiveness of both concepts. For example, the entry in The Reader's Companion to U.S. Women's History authored by Gloria Steinem and Diana L. Hayes, treats "womanist and womanism" as "culture-specific and poetic synonyms for Black feminist and Black feminism" (639). On the other hand, Carol Marsh-Lockett points out in her 1997 definition in The Oxford Companion to African American Literature that Walker's concept of womanism is not only antithetical to white feminism, but also, to a certain degree, to black 
brought back appreciation for strong, anti-patriarchal female characters in the tradition of Hurston's Janie Crawford, including: Merle in Marshall's The Chosen Place, The Timeless People; Pilate and Circe in Morrison's Song of Solomon; Sula in Morrison's Sula; Meridian in Alice Walker's Meridian; and Ruth in Alice Walker's The Third Life of Grange Copeland. In the 1980s, however, womanist novels, such as Mama Day, Praisesong for the Widow, Tar Baby, The Salt Eaters, Abeng and No Telephone to Heaven, started to glorify ancestral mothers and picture communal mothering as the main and multivalent practice of black female resistance. Moreover, as Dubey has observed, generational continuity, which was "an emergent impulse visible in Corregidora and Meridian," came to be seen in the following decade as a "redemptive [possibility]," which, together with the idealization of mothering, circumscribed black female agency (Dubey, Black Women Novelists 161).

Naturally, womanism was not exclusively Alice Walker's brainchild; it was rather the collaborative effort of all BWR writers and critics, such as Michele Wallace, Mary Helen Washington, Frances Beale, Barbara Christian, Mari Evans and Eleanor Taylor, to name just a few, all of whom struggled to legitimize the material and literary legacies of black foremothers. But it seems that Walker's "cultural intervention" pushed womanism to the forefront of the black feminist agenda and re-defined the Black Aesthetic as a womanist aesthetic (Broeck, “The Urgency of Petunias” 225). Walker's ideological and artistic trajectory shows that BWR writers' views on key black nationalist ideas pertaining to motherhood, matriliny, memory and heritage crystallized in the late 1970s and early 1980s to shape a black "matrifocal nationalism" (Boehmer, Stories of Women 101). It saw "Janies" finally adopting the role of national mothers, matriarchs metamorphosing into keepers of "authentic" black traditions, and the idea of "the reproductive cycle ... as a self-perpetuating vicious circle of oppression" transmuting into matriliny as "the only means of preserving the continuity between the past of the black historical and cultural heritage" (Dubey, Black Women Novelists 160). While in the 1970s, BWR writers repeated, with a great deal of ambiguity, the black nationalist gesture of constructing a new identity in opposition to the mother, the 1980s witnessed a dramatic revalorization of motherhood, mothering and feminine folk heritage. Womanist novels of the 1980s, such as Mama Day, Praisesong for the Widow, Abeng and No Telephone to Heaven are also distinguished by their celebratory embrace of the folk as the foundation of a newly-discovered black female authority.

The 1980s' novels also reflect a departure from "social science fiction” (Albert Murray, qtd. in Wall, Changing Our Own Words 9); that is, fiction that treats literature as a "mimetic representation of sociology" (Wall, ibid.). BWR fiction of the 1980s moves from the model of realist, or naturalist social protest literature, which was

feminism. See also Patricia Hill Collins, "What's in a Name? Womanism, Black Feminism and Beyond.” The Black Scholar, vol. 26 no 1, Winter/Spring 1996, pp. 9-17. 
supposed to provide unambiguous and straightforward criticism of reality, towards formal experimentation, as evidenced in Morrison's more complex use of the gothic, Kincaid's modernism, and Cliff's non-realistic/postmodern techniques. In the 1980s, the BWR infused realist writing with magical, mythical and surreal elements borrowed from the black folklore tradition. In this way, these writers, inspired by the strong womanist current, shifted the center of gravity of the Second Renaissance to the heartland of Black Atlantic cultures in the New World.

I call this common geographic homespace, after Immanuel Wallerstein, the extended Caribbean. It encompasses a stretch of a geographic space that stretches from northeastern Brazil to Maryland, with the Caribbean archipelago at its center. It is the place of initial displacement of Africans and the place where slavery developed in its harshest form. But the extended Caribbean is also a mythical place, to which many authors of the black diaspora returned in order to turn the tide of History and reconnect with their peoples' ancestral African past. Next to the northern ghetto and ancient Africa, which were the "frames of reference" for black nationalists and Afrocentrists respectively, the extended Caribbean became, for BWR writers, another place with huge mythical and regenerative potential.

This shift in geographical focus, accompanied by a preference for non-realistic modes of writing, was fundamental, because it allowed the writers of the 1980s to express what they deemed to be "eternal" and "essential” truths about Black Atlantic cultures. It is important to note that even although some 1970s' novels, most notably Song of Solomon, which I will discuss later, hinted at the existence of such transcendental truths, most of the novelists in the 1970s did not seem to believe that they had access to them. Therefore, as Dubey argues, in the concluding chapter of her monograph, it was only in the 1980s that BWR fiction "engaged in salvaging the values of the community, the oral heritage, and of the historical past in ways that redefine[d] the black nationalist constructions of these terms" and "position[ed] the Dessa Roses, the Sethes, and the Mama Days as the 'mothers' of Black political and cultural resistance” (Black Women Novelists 161). This passing of African American history and heritage through the feminine line, which was such a vexed issue in the fiction of the 1970s, emerged, in the 1980s, as a major means of black female selfempowerment. For the first time, African American women writers saw themselves as embodiments of a national ethos, and as national daughters who were as important to the national survival as "the sons of the soil" (Boehmer, Stories of Women 14). Women, with their power to "create generations" and pass on to them the "eternal" values of black (nationalist) identity, placed themselves at the heart of the nationalist-womanist project.

One novel that is conspicuously absent from Dubey's otherwise brilliant study about the BWR and nationalism in the 1970s is Song of Solomon, a womanist novel that in many ways reiterates the concerns of Dubey's monograph. Song of Solomon also focuses on class and gender diversity within black communities and shows divisions between Southern and Northern black cultures. It engages with discourse 
about black matriarchy and motherhood, and questions the efficacy of extreme militant black nationalism. This novel, like other narratives discussed by Dubey, such as The Third Life of Grange Copeland, Sula, Eva's Man and Corregidora, is a form of Bildungsroman that traces the social and political awakening of its male protagonist, Milkman, whose quest for money eventually turns into a quest for roots and spiritual integrity. The novel foreshadows the valorization of Southern folklore that occurred in the 1980s as Milkman's quest takes him South, to the extended Caribbean, where he discovers the history of his family and his "tribe" and immerses himself in its "authentic" black indigenous culture. Thus, the novel fits into the paradigm of the "intergenerational impulse" that Dubey rightly sees as an emerging feature of the 1980s' BWR novels. In short, Song of Solomon has all the elements that attracted Dubey's attention in other 1970s' novels, and yet it is not even fleetingly mentioned in her monograph. In many respects, Song of Solomon was an avant-garde novel that outdistanced most of Morrison's contemporaries by a few years in its celebration of female folk heritage, the power of black vernacular and mythical patterns.

This gap in Dubey's study had already been filled by Harry Reed's inspiring article, "Toni Morrison, Song of Solomon and Black Cultural Nationalism," which was actually written ten years earlier, and was the first publication on the BWR and cultural nationalism. Strangely, none of the later studies on the BWR and cultural nationalism acknowledged Reed's pioneering observations. In this article, Reed claims that in Song of Solomon, Morrison is "working on the broadest possible imaginative nationalist canvas" (52), and that the novel is "a major contribution to nationalist thought" (52). He also describes it as a "Pan-African" novel (Reed 53), incorporating motifs from African cultures, such as flying, which implies a spatial and temporal connection between Africa and America, as well as between the past and the present. Reed sees Morrison's “Africanism” and her endorsement of cultural nationalism as the greatest achievement of her fiction. To his mind, it bears witness to the fact that "BCN [black cultural nationalism] ... [is] the most important foundation of black survival” (Reed 51). The article lavishes praise on Morrison and other writers of the Black Women's Renaissance for hammering this simple truth into the political consciousness of post-civil-rights black America.

Interestingly, Reed lauds Song of Solomon's black female characters as being both metaphors and metonymies of black cultural nationalism. On the one hand, he sees the novel's maternal figures, such as the wise Pilate, the ancient Circe, and even the "small” Ruth, as prototypes of "nationalist archetypes" (Reed 52), saying that "[t]heir personae incorporate bits of Ancient Africa, New World Slavery, Southern Reconstruction and the present" (Reed 53). On the other hand, however, he invests in these women the power of "regenerating the community from within" (ibid.). Pilate, in particular, grows in his essay to mythical proportions as an "old timey" and an "embodiment of black wisdom, which gives Pilate an equilibrium" that none of other female characters possesses (57). Pilate does not yet have the level of self-awareness of the 1980s' wise grandmothers; nevertheless "her unconscious Africanism is demonst- 
rated through her identification with black culture, the aura of magic, and sense of deep wisdom," (Reed 53). Though she cannot work magic or heal her broken-hearted granddaughter, she does herald the triumphant advance of the 1980s' conjure women. Pilate, who does not have a navel, a fact that seems to suggest that she was not human-born, can be considered as the Ur-mother, or the first mother, for these later maternal figures. Reed describes the effect of her lack of a navel as follows: "Pilate who never mothered anybody, was helpful to everybody, but who also was believed to have the power to step out of her skin, set a bush on fire from 50 yards, and turn a man into a ripe rutabaga - all on account of the fact that she had no navel” (94). All the female characters in Song of Solomon, as Reed aptly comments, "appear as the carriers of the old way. Men on the other hand tend to move away from the ancient wisdom: they run, make money, and challenge whites in both real and symbolic confrontations" (62). And while men lose themselves in these misguided pursuits, they miss the point that the only way for black people to make headway is, as Reed puts it, by "validat[ing] black culture and reaffirm[ing] its adaptive survival power, its creativity amidst oppression, its life-affirming qualities, as well as ancient wisdom and humanity and its capacity for survival” (63). According to Reed, black women are uniquely equipped to preserve and pass on "the wisdom of ages," and he says that "Morrison implies [that black people] are all poorer for [their] inability to understand, to accept, and to utilize the old ways" (57).

In Reed's opinion, what makes this novel "ripe with a cultural nationalist thrust" (51), is its thematic focus on the search for roots, family and identity, and the pursuit of growth, autonomy and commitment, as well as Morrison's unshaken belief in the regenerative potential of traditional folk cultures. As Milkman travels through "the oral oriented culture" of the American South (Reed 60), he learns the "collective wisdom" of Southern communities and "comes to appreciate the dynamic of black life stretching back over generations" (ibid. 61). What also seems important is that Song of Solomon has an emblematic dimension, which is so characteristic of national allegories, because, as Reed argues, it is a novel about both "the transformation within the individual and within the race" (53).

What anchors this novel in the 1970s' political climate is Morrison's concern not to present matriarchy as a viable alternative to "normal" black family. For example, in "Rootedness," she seems to endorse black nationalist criticism of matriarchs like Pilate by criticizing all-female households, often approved by black female critics, as a dangerous pathology, stating that "the disability we must be on guard against for the future [is] the female who reproduces the female who reproduces the female" (344). Moreover, Morrison seems to bow to black nationalist ideology by making the national family plot revolve around a man - the son of the nation. Milkman is at the center of the quest for roots, and he is surrounded by less important female helpers who unconditionally love, support and guide him, and forgive him all his betrayals and mistakes. 
This fact has led Trudier Harris to criticize Song of Solomon and other novels by Morrison, such as Sula, Tar Baby and Beloved, for being unashamedly anti-feminist. Harris underlines that fact that Song of Solomon was published when black nationalism was still strong, and consequently all women were expected to be feminine and secondary to masculine aspirations and actions. This leads Harris to conclude that in Morrison's fiction, there was an inherently male-centered perspective: "females are of value in direct proportion to their assistance in male objectives; more often than not, they suppress their desires, indeed sacrifice their lives and/or futures to assist males" (Fiction and Folklore 187). The same perspective, contends Harris, compelled Morison to "kill" Sula, who, as bell hooks has also observed, was too masculine, independent and radical to stay alive. The same impulse, according to Harris, made Morrison condemn other female characters in her fiction, such as Jadine, for example, who was put down for her Eurocentric selfishness in Tar Baby, or Sethe, who was punished by the ghost of the baby in Beloved.

Harris makes a particularly convincing case for her claim that women in Morrison's fiction were victimized by what she calls "traditional folkloristic patterns" (Fiction and Folklore 114), which coincide with what I describe as the volkish tradition. She observes that the characterization of Pilate is a "blending of secular and sacred traditions, natural and supernatural concerns" (ibid.) but says that one would be wrong to assume that this endows Pilate with any real power. Song of Solomon traces Milkman's empowerment through his immersion in the folk culture of the South. There he learns manhood, commitment and generosity, and finally becomes one of the flying Africans, thanks to Pilate, the nurturing mother who makes the return to the South possible and pays for it with her life. All the women in the novel sacrifice themselves for Milkman: his sisters and his cousin and lover Hagar. All of them are rejected by Milkman as his own desires take precedence over those of women in his family. Hagar is "a sexual outlet in the way that his sisters are maids - convenient and exploitable" (Harris, Fiction and Folklore 110). Harris suggests that when Hagar tries to place "duty squarely in the middle of their relationship," he instantly tries to "think of a way out," and "Hagar presents her body as one of the bridges over which Milkman Dead walks into his own humanity and manhood" (Fiction and Folklore 113). According to Harris, Morrison practically destroys Pilate's family, since Hagar and Pilate both end up dead so that this one man can reach maturity.

In 1981, the year that ushered in the second decade of the BWR, Morrison published another novel, Tar Baby, which featured a Bildungsroman-type education of a son of the soil, aptly named Son, who, in one of the best-known lines from the novel rhetorically asks his Sorbonne-educated lover, Jadine, "whose culture she is bearing." Tar Baby can also be read through the lens of psychological feminism to illuminate Jadine's need for independence and her cultivation of an individualistic identity. Or it can be read through the black folkloric figure of the tar baby, a female trickster attempting to deceive the positive hero embodied by the animal character, Br'er Rabbit, from the Uncle Remus stories (1880). In that second reading, Jadine is depicted as a 
tar baby trying to trap Son, the son of the soil, in the American myth of social mobility and materialism. Jadine is a modern, liberated woman who considers herself a citizen of the world. But Morrison wants to make the point that a vital part of a black woman's identity is her loyalty to her nation, to "the tribe." The cosmopolitan Jadine is therefore presented as a person whose sense of self has been eroded by dislocation and acculturation to western values. Morrison confronts Jadine's sense of herself with other black characters' views of her. These are mostly females whose identities are "authentic," stable, and firmly rooted in African American folklore, characteristics which Jadine does not find appealing at all. These "truly black" women, black mothers, grandmothers and sisters, to whom Morrison's novel is dedicated, have more personal integrity, moral fiber and authority than Jadine, and they successfully disrupt her image of herself.

Much of the action of the novel focuses on their attempts to bring Jadine back into the fold by teaching her what genuine black female identity should look like. For example, the "swamp women," who appear as trees in a scene in which Jadine is trying to get out of a mythical part of the jungle, try to re-claim Jadine as their daughter. The trees are described as having female and maternal identities, while she is "a runaway child restored to them but fighting to get away from them, their exceptional femaleness" (Tar Baby, 155, emphasis added). Although "they were first delighted when they saw her, the girl's desperate struggle to be something different than they were" makes them "quiet," "arrogant" and "mindful of their value" (ibid. 266).

Then there are the "night women," who also want to teach Jadine a lesson about what "exceptional femaleness" means. In a room, which reminds her of "a cave, a grave, the dark womb of the earth" (ibid. 225), Jadine is again put in the position of a prodigal daughter confronted by foster mothers, who are angry and demanding her attention. She sees the night women as "the mamas who seduced [her black lover Son] and were trying to lay claim on her" (ibid. 157). From the African woman in yellow, who spits at the "inauthentic" Jadine in a supermarket, to the women in the trees and the night women, all of the black women in the novel question Jadine's womanhood. Jadine's re-education ends in failure, and as a consequence she is condemned as a woman who, in the words of Thérèse, another "substitute" mother in Tar Baby, has "forgotten her ancient properties" (ibid. 263). Morrison obviously favors Son over Jadine, who is depicted as a social-climber - snobbish, demanding and white-oriented. Jadine is dismissed as a traitor to her "tribe" because she wants to "make it" in the white world. Son, by contrast, symbolizes the resistant black culture that tenaciously refuses to submit to the domination of white civilization and tries to rescue Jadine from its clutches. He fails because, as readers are told, Jadine is a "Yalla," and "it's hard for them [yellow women] not to be white people, most never make it. Yallas don't come to being black natural-like. They have to choose and most don't choose it" (ibid. 266).

Thus Morrison, who intelligently presents arguments in favor of Jadine's worldview, nonetheless, passes a harsh judgment on her. She does so by contrasting 
Jadine's worldview with that of Son, the African woman, the swamp and night women and other black characters from "authentic" folk backgrounds, whose identities are securely rooted in their communities' cosmology. In the words of Harris:

Jadine's talents are undercut by the negative response written into the text in evaluation her actions. Her efforts to help Son might be annoying, but finally they are more acceptable than her bid to be an independent, self-determining woman. Or we might say that the tone of her assistance is too "masculine," too much on a level of male/female equality than Son's fragile ego can take ... (Fiction and Folklore 188).

Jadine is despised, spat on and manipulated just because she wants to be someone other than an obedient daughter and eventually a "culture bearing" mother. Consequently, as Harris asserts, Morrison's novels "seem to continue the use and abuse of black women's characters" by making them victims of the volkish tradition that is "generally devalued by males" (Fiction and Folklore 188). She accusingly asks: "Is there any female character in Morrison's work who can fulfill herself and not be destroyed or not be judged for doing so? Must all women be subsumed under some community standard, or ostracized if they do not adhere to such standards?" (Fiction and Folklore 189).

Accusing Morrison of misogynist intentions seems too harsh a judgment since it is clear to me that Morrison's fiction of the 1970s and 80s tried to strike a balance between her appreciation of the wise foremothers and her concern not to alienate the national sons. Morrison clearly cared about the sons of the nation (as Baby Suggs suggests in Beloved when she says: "A man is nothing but a man, ... [b]ut a son? Well now, that's somebody" 23), and she wanted black men to fit into her national scheme, or "to inhabit the nation practiced by women," as Thorsson asserted, speaking about Mama Day (Women's Work 126). ${ }^{37}$ That balancing act is not so conspicuous in the fiction of other writers of the BWR, who, in the 1980s, seemed to have awakened to the fact that it is the womanist daughter who should be recognized as the driving force of the black nationalist project. Whilst in the 1970s' novels, female characters often accepted their secondary position vis-à-vis men, in the 1980s' fiction of the BWR, a matrilineal perspective supersedes the patrilineal one, and feminine folk iconography becomes a dynamic source of the womanist novel that empowers women.

One vivid example of that iconography can be found in a parable recounted by Hurston in her collection Mules and Men (33-8). Its female protagonist, Mathilda,

37 Thorsson argues that the fact that George narrates part of the novel (alternating with Cocoa in a call-and-response pattern) "indicat[es] the importance of men in fashioning the African American nation. Their job is not to found and defend a nation but to inhabit the nation practiced by women" (Women's Work 126). It is disconcerting, though, that George does not survive his visit to Willow Springs. He dreams about Willow Spring becoming his "nation," but he becomes part of it only after he dies. 
maintains that God made man and woman equal in strength, but the man wanted to rule and persuaded God to make him stronger. To compensate for that, God gave women the keys to the kitchen, the bedroom and the cradle, while the devil taught her how to use them. Thus, the woman gained control over access to food, sex and reproduction, which ultimately gave her more power than man. Only after the man "submit[s] hisself to de woman," Mathilda says, will the woman open the door. The heroines of the 1970s were, by and large, docile and hardworking, they suffered from poverty, racism and sexism, but they tried to come to terms with their men. In the 1980s, by contrast, they seemed to have learned how to use the keys that God had given them. This stark reversal in the gendering of privileges made black women, particularly mothers, beneficiaries of the traditional folkloric belief systems, which at the same somewhat devalued black men. The expression of gender identities through the prism of folk heritage in the 1980s' novels of the BWR changed the construction of black masculinity and femininity in a way that reinforced the position of maternal figures in the national imaginary. This literary move had far-reaching political and cultural implications for how black men and women and their social roles were perceived in reality (L. Smith, "Heritage, Gender and Identity” 159). 